\title{
Dental treatment and recommended management in patients at risk of infective endocarditis
}

\author{
Katarzyna J. Błochowiak \\ Department of Oral Surgery and Periodontology, Poznan University of Medical Sciences, Poznan, Poland
}

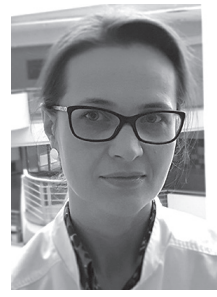

Kardiochirugia i Torakochirurgia Polska 2019; 16 (1): 37-41

\begin{abstract}
Infective endocarditis (IF) is found in high-risk groups with congenital or acquired cardiac defects. It is caused by episodes of short bacteraemia. The magnitude and duration of bacteraemia caused by dental procedures are decreased by using antibiotic prophylaxis (AP). The aim of this study is to describe and discuss all clinical implications related to IF and dental procedures, and AP before invasive dental procedures. Maintenance of optimal oral health and hygiene is more important than AP in decreasing the risk of IF. Routine daily activities are associated with a similar risk of bacteraemia. It is estimated that antibiotics use in dentistry may represent up to $10 \%$ of total antibiotics use, and the risk of developing bacterial resistance should be taken into account.
\end{abstract}

Key words: infective endocarditis, bacteraemia, antibiotic prophylaxis, dental surgery.

\section{Introduction}

Infective endocarditis (IF) is an infectious, potentially life-threatening disease of the heart valves or endocardium, which is caused by bacteria that can affect different organs. Its incidence is estimated to be 1 to 5 cases per 100,000 inhabitants [1]. It is often found in high-risk groups with congenital or acquired cardiac defects. Invasion of the bloodstream by microbes that can colonize the damaged sites can result in IF. Episodes of short bacteraemia can trigger IF in at-risk patients. For this reason, many studies have focused on prevention or on decreasing the magnitude and duration of bacteraemia caused by dental procedures using antimicrobial agents. Antibiotic prophylaxis (AP) prior to invasive dental procedures remains the recommended management for 'high-risk' patients in most countries of the world. Currently, there are three main recommendations for IF prophylaxis made by the American Heart Association (AHA), the European Society of Cardiology (ESC), and the United Kingdom's Na-

\section{Streszczenie}

Infekcyjne zapalenie wsierdzia występuje w grupach wysokiego ryzyka rozwoju wrodzonych lub nabytych chorób serca. Choroba wywoływana jest przez epizody krótkotrwałej bakteriemii. Wielkość i czas trwania bakteriemii spowodowanej zabiegami stomatologicznymi zmniejszają się w wyniku zastosowania profilaktyki antybiotykowej. Celem pracy jest przedstawienie i omówienie implikacji klinicznych infekcyjnego zapalenia wsierdzia i zabiegów stomatologicznych oraz profilaktyki antybiotykowej stosowanej przed inwazyjnymi zabiegami stomatologicznymi. Utrzymanie optymalnej higieny i zdrowia jamy ustnej jest ważniejsze w redukcji ryzyka infekcyjnego zapalenia wsierdzia niż profilaktyka antybiotykowa. Rutynowe czynności w jamie ustnej są związane z podobnym ryzykiem wystąpienia bakteriemii. Stosowanie antybiotyków w stomatologii stanowi ponad 10\% całkowitego użycia antybiotyków i niesie ze sobą ryzyko rozwoju oporności bakteryjnej.

Słowa kluczowe: infekcyjne zapalenie wsierdzia, bakteriemia, profilaktyka antybiotykowa, chirurgia stomatologiczna.

tional Institute for Health and Care Excellence (NICE). Recently, the use of AP has been reduced. The effectiveness of AP in reducing IF prevalence and its safety and possible benefits are questioned. The possible impact of other IF promoting factors and the impact of oral health are highlighted. These doubts have been reflected in the current global strategy against IF and in new recommendations. In 2008 the NICE produced guidance recommending cessation of AP for preventing IF. In contrast, the AHA and the ESC produced guidelines in 2007 and 2009, respectively, which recommended cessation of AP only for individuals at moderate risk of IF [2-6].

The aim of this study is to describe and discuss all clinical implications between IF and the dental procedures and the effectiveness and safety of AP administered before dental procedures according to the new guidance. An additional aim is to present the possible strategies and recommendations in dental management. 


\section{Assessment of bacteraemia and risk of infective endocarditis related to dental procedures}

The most important issue is to estimate the real risk of IF related to bacteraemia caused by dental procedures and to analyse this potential health risk with the current orodental status, oral hygiene and the type of dental procedure. Maintaining good oral hygiene and infection control can decrease the incidence of IF in the moderate-risk group of patients and can eliminate the necessity of AP of IF. There are controversial data about the differences in oral health in normal patients and patients with congenital heart diseases. Some research findings have shown that oral streptococci, the main cariogenic organisms as well as the main causative organisms of IF, grow more in the oral cavity of cardiac patients [7]. Viridans streptococci are responsible for dental caries, pericoronitis, and subacute IF. The most frequently isolated viridans Streptococcus from IF patients is S. sanguinis (31.9\%), followed by S. oralis (29.8\%) [8]. They are also responsible for $40-60 \%$ of IF cases. Cardiac patients are prone to periodontitis, caries and other dental infections. In dental infections, the risk increases. It has been estimated that from $8 \%$ to $10 \%$ of $\mathrm{IF}$ is related to oral infections with no oral bleeding treatment. This is due to the permeability of the epithelium surrounding the tooth-gingival tissue interface and the prostaglandins in blood that increase the number of leukocytes and fibrinogen. The blood circulation is reduced and bacteria may enter [9]. The prevalence of caries and gingivitis among children with congenital heart diseases is much higher than in healthy children [7]. Periodontal disease is another risk of endocarditis in patients suffering from congenital heart diseases. Bad oral hygiene, accompanying systemic diseases and taking different medications are risk factors for periodontal disease in cardiac patients. Some research findings have suggested a positive correlation between periodontal disease and congenital cardiovascular problems [10]. A higher risk of caries and periodontitis in cardiac patients increases the incidence of IF through higher levels of potentially harmful bacterial species, as well as by the higher frequency of dental procedures. The role of dental hygiene in cardiac patients as a possible cause of bacteraemia is confusing, too. Brushing or flossing may increase the risk of oral streptococcal bacteraemia on a short-term basis, but may also decrease the risk of IF on a long-term basis. The literature presents conflicting results concerning the relationship between gingival or periodontal disease and the risk of bacteraemia after tooth extraction. According to Lockhart et al., there is a direct relationship between dental plaque and gingival inflammation parameters and viridans streptococcal bacteraemia [11]. On the other hand, Duval et al. found no differences concerning either the calculus score or gingival inflammation between cases and controls, suggesting that the increased risk of IF-associated bacteraemia in patients with poor oral hygiene may be insufficient to induce endocarditis [12]. It should be emphasised to patients that maintaining optimal oral health and hy- giene and regular dentist visits may reduce the incidence of bacteraemia from brushing teeth, chewing food and daily activities, and thus are particularly important in reducing the risk of IF. Maintenance of optimal oral health and hygiene is more important than prophylactic antibiotics in reducing the risk of IF $[4,5,9,13]$. Epidemiological studies have estimated that $14 \%$ to $20 \%$ of cases of IF are related to oral hygiene [9]. Oral hygiene habits such as brushing, using toothpicks, flossing or chewing can result in bacteraemia during non-exposure periods. The microtrauma caused by these daily activities induces bacteraemia in similar proportions to those of invasive oral procedures for which AP is recommended. The fact that the cumulative non-exposure periods are much longer than the exposure periods strongly suggests that most cases of IF are due to everyday life bacteraemia [14]. There is sound scientific evidence that brushing a child's teeth twice a day causes 154,000 times higher risk of bacteraemia than a single tooth extraction. It is also estimated that there is a 5.6 million times greater risk of suffering from bacteraemia due to toothbrushing than due to a single dental tooth extraction [9]. The incidence of bacteraemia for tooth extraction ranges from $18 \%$ to $85 \%$, for periodontal surgery from $60 \%$ to $90 \%$ and for toothbrushing or irrigation from $7 \%$ to $50 \%$. Routine daily activities unrelated to a dental procedure are associated with a similar risk of bacteraemia [13]. These activities are shorter and more frequent than dental procedures. Moreover, most people only visit a dentist once or twice per year, and so are only exposed to a bacteraemia related to dentist or dental hygienist manipulations on rare occasions, whereas they are exposed to transient bacteraemia from daily activities very frequently. Even though these daily transient bacteraemia are of low grade and of short duration, they are of high incidence. There is only a small percentage of IF related to dental procedures; the majority of IF is associated with oral hygiene habits. The incidence of bacteraemia ranges from $20 \%$ to $68 \%$ for toothbrushing and flossing, from $20 \%$ to $40 \%$ for the use of wooden toothpicks, from $7 \%$ to $50 \%$ for the use of water irrigation devices, and from $7 \%$ to $51 \%$ for chewing food [13]. It is clearly not realistic to administer prophylaxis against these random daily physiological bacteraemia. Thus, if prophylaxis is administered prior to a once-yearly or twice-yearly dental procedure, even if it is $100 \%$ effective, only an exceedingly small proportion of cases of IF would be prevented [13]. It is estimated that only $5.3 \%$ of cases would have been potentially prevented if antibiotic therapy were $100 \%$ effective and given to all patients at risk in dental treatment [9]. Furthermore, it has been observed that in many cases the onset of endocarditis occurred many months after the procedure or that the causative agent was not a bacterial species that lives in the oral cavity [13]. The prevalence and intensity of bacteraemia vary among different surgical procedures. The oral cavity is a reservoir of over 700 different species of bacteria. Therefore, any procedure capable of causing a breach in the oral mucosal barrier places the internal body environment in contact with the 
highly contaminated oral cavity, resulting in potentially harmful microorganisms penetrating into the systemic circulation. All surgical dental procedures are characterized by a significantly higher prevalence of bacteraemia compared to non-surgical procedures $[9,15]$. The highest risk of bacteraemia is estimated for adult dental extractions (58$100 \%)$ and for extractions of third molars (10-62\%), respectively [9]. The extraction of impacted or partially erupted third molars results in a higher prevalence of bacteraemia than more aggressive maxillofacial surgical techniques. Quite a low risk of bacteraemia is associated with suture removal (10\%), incision and drainage of an abscess (12\%) and osteosynthesis plates removal (8\%) [9]. There is no significant risk of bacteraemia in implants. This risk is assessed at $7 \%$. The implant placement via a mucoperiosteal flap does not carry a significant risk of producing bacteraemia compared with the baseline percentage. During the implant placement, the periodontal space is not invaded, and this space represents the critical region from which oral bacteria enter the bloodstream [9]. When evaluating non-surgical dental interventions, the prevalence of bacteraemia is similar after conservative dental procedures and after other orthodontic procedures and is lower after performing root canal treatment (0-42\%) [9]. The prevalence of bacteraemia related to administration of local anaesthesia is estimated at $73 \%$. Higher risk of bacteraemia is typical for periodontal surgery and periodontal prophylaxis and scaling and root planning. The association between periodontal treatment and bacteraemia ranges from 13\% to $80.9 \%$, periodontal probing $20 \%$ to $43 \%$, and periodontal surgery $60 \%$ [16]. Non-surgical periodontal therapy leads to a total degree of positive bacteraemia of $46 \%$ [16]. It is associated with special bacterial flora of the periodontal pocket. Over 700 species of bacteria have already been identified in the oral cavity, 400 of which were found in the periodontal pocket adjacent to the teeth. Streptococci represent a significant part of the flora around the teeth, especially in the supragingival plaque, and they are frequently associated with IF [17]. Because of the high prevalence of bacteraemia in periodontitis, patients at risk of IF should receive AP [18]. Orthodontic treatment is considered to be relatively atraumatic and non-invasive, with only a remote possibility of inducing bacteraemia. Among the selected orthodontic treatment procedures, such as alginate impression, separator placement, band cementation and arch wire change, separator placement demonstrated the highest prevalence of bacteraemia [19]. Birlutiu et al. presented the case of a female patient, who had developed IF with Streptococcus viridans associated with fixed orthodontic appliance, located on the mitral valve, without previous cardiac pathology [20]. The same authors reported a case of IF caused by Abiotrophia defectiva in a patient treated with a fixed orthodontic appliance [21]. Aortic valve endocarditis has also been described as a consequence of a tongue piercing [22]. In the assessment of the bacteraemia in IF development, in addition to the magnitude of bacteraemia, the duration of bacteraemia and other modifying factors should be considered. Bacteraemia peaks during the first 2 minutes following tooth extraction or an invasive dental procedure, and falls over time. However, oral bacteria have been found in blood cultures at 1 to 45 minutes after tooth extraction [23]. The study evaluated the presence of bacteria in peripheral blood before and immediately after scaling and root planning and 30 minutes after this procedure. The highest incidence was observed immediately after treatment $(70 \%)$ and decreased 30 minutes after treatment (25\%) [18]. The reduction in bacteraemia over several minutes after dental instrumentation is due to the effectiveness of the host defence system in rapidly clearing microorganisms from the blood. The capability of neutralizing the microorganisms in the blood varies among patients and may represent an additional risk factor for developing IF [18]. Most causative bacterial species are fought within the first 30 minutes of the procedure. However, some pathogenic species can persist for at least 60 minutes after brushing and extraction without an antibiotic [17]. Anaerobic bacteria are the most persistent bacteria in the blood [23]. Some studies show that the incidence of bacteraemia decreases over the periods similarly in all three groups, the highest at 30 minutes postoperatively followed by 60 minutes and 90 minutes postoperatively. This can be attributed to the fact that under physiological conditions, the bacteria are transferred from the bloodstream into tissues and are rapidly cleared by the reticuloendothelial system [24]. Molecular analysis reveals that dental extraction and supragingival scaling are associated with a similar incidence of bacteraemia in groups receiving or not receiving prophylactic antibiotic therapy. The same analysis does not reveal significant differences in the incidence or magnitude of bacteraemia between the two patient groups either 5 or 30 minutes after each of the procedures is evaluated. However, blood culture reveals that antibiotic therapy reduces viable cultivable bacteria in the bloodstream after tooth extraction [25]. Some research has studied the effect of the duration of surgery on bacteraemia and found that when the operation exceeds 100 minutes the frequency of postextraction bacteraemia is $96 \%$ compared to $67 \%$ when the surgery is of a shorter duration. The prevalence of bacteraemia is higher in longer surgery (> 65 minutes) than when the duration of surgery is shorter ( $\leq 65$ minutes) [24].

\section{Assessment of the effectiveness and safety of antibiotic prophylaxis}

Currently, in all recommendations related to the prophylactic use of antibiotics a thorough assessment of all potential benefits and drug-related adverse effects should be considered. AP acts not only by killing bacteria, but also by inhibiting bacterial adherence $[23,26]$. All antibiotics applied in prophylaxis of IF are targeted against streptococci $[23,26]$. An unprofitable balance of effective antibacterial action and drug-related adverse effects is one of the reasons for reducing antibiotic use, especially in patients at low and moderate risk of IF. All recommended antibiotics are effective against the most common causative bacterial 
species of IF and are now widely advocated to protect atrisk patients. However, their frequent and widespread use generates drug-resistant bacterial species, such as viridans group streptococci (VGS). The frequency of multidrug-resistant VGS has increased significantly during the past 25-30 years. This is turn has reduced the number of effective antibiotics available for the prophylaxis of IF. The long-term use of amoxicillin causes the emergence of resistant strains and the repeated use of amoxicillin can elevate the ratio of resistant strains in the entire oral microbiota [26]. It is estimated that antibiotics use in dentistry may represent up to $10 \%$ of total antibiotics use, and these results have to take into account the risk of developing bacterial resistance [9]. Although the total number of amoxicillin-resistant strains may be extremely low, and even though oral bacteria invade the bloodstream during invasive dental procedures, the median detection rate for amoxicillin-resistant strains in healthy subjects who took amoxicillin within the past 3 months was reported to be $10.9 \%$, which was higher than that of subjects (2.4\%) who did not [26]. Moreover, present studies demonstrate that amoxicillin-resistant strains may be more prevalent in patients at risk of IF as compared to healthy individuals. In addition to the development of resistant bacterial species, there is also a high risk of severe adverse reactions associated with antibiotics use. While a single dose of amoxicillin or ampicillin prior to dental procedures is treated as safe for individuals who do not have a history of a type I hypersensitivity reaction to penicillin, the occurrence of antibiotic-related adverse effects after amoxicillin use is reported in $2.9 \%$ of patients. These drug-related adverse effects include anaphylactic reactions, skin reactions, gastrointestinal disorders, liver problems and haematological complications. Hypersensitivity reactions to penicillin or anaphylaxis occur in $0.04 \%$ to $0.11 \%$ of cases of therapy with penicillin. This adverse effect is triggered more often after intravenous administration than oral administration [9]. It is worth noting that deaths from anaphylactic reactions to antibiotics may be five to ten times more common than deaths from IF. Clindamycin, the second prophylactic choice, is associated with a high rate of adverse drug reactions (ADR), including 13 fatal and 149 non-fatal ADR reports per million prescriptions. The most severe $A D R$ related to clindamycin is infection with $C$. difficile [27]. These data suggest that the indiscriminate use of antibiotics increases the risk of adverse reactions and may exceed the risk of IF. Some trials indicate that AP is effective in reducing the incidence of bacteraemia, but this may not translate into a statistically significant protective effect against IF in patients at low risk of disease. Most studies evaluate the effectiveness of the AP only in reducing bacteraemia, but not in reducing IF [28, 29]. Bacteraemia is only the first initial step in IF development. Infective endocarditis is a multifactorial disease, with multiple promoting factors which must all be considered in an IF prevention strategy [12]. These promoting factors include the orodental status, orodental hygiene, the type of oral flora and the individual patient's defence mechanisms. Most of the randomized clinical trials conducted do not consider these promoting factors, and concentrate on the effectiveness of AP in reducing bacteraemia. Furthermore, the potential adverse effects of AP may outweigh its benefits. In global strategies for the prevention of IF, additional factors, such as the health risks, cost-effectiveness, and practicality of the routine use of AP, should also be considered. In comparison with no AP, both amoxicillin and clindamycin AP are associated with lower costs and better health outcomes for both high-risk and all-at-risk populations [30]. Because of the serious consequences and high costs associated with IF and the comparatively low costs associated with AP, these results demonstrate that $A P$ is cost-effective in preventing IF, particularly for those at high risk, even when the number of IF cases prevented is very low [30].

\section{Possible additional strategies and management in the prevention of infective endocarditis}

Limitations in the use of antibiotics in moderate and low risk groups of patients resulted in the introduction of new management and strategies in prevention of IF. They include new recommendations in dental treatment. These concentrate on maintaining good oral hygiene and infection control [28]. All international societies encourage rational antimicrobial use and condemn the indiscriminate use of AP for dental procedures. Because of the increased rate of amoxicillin-resistant bacterial strains, the new quinolone antibiotics might become a possible alternative option for the prevention of IF [26]. According to the rules of rational AP, if an antibiotic is provided, dental treatments should be performed to reduce the episodes of this antibiotic. If several prophylaxis episodes are required, they should take place at two-week intervals at least. Treatment should be stopped for 3 to 4 days if the patient is taking other antibiotics [9]. The next recommendation is to disinfect the oral cavity before all dental procedures. This management can replace AP and is advocated especially in moderateand low-risk groups of patients. According to Sendi et al., the bacteraemia incidence after tooth extraction can be reduced via pre-interventional mouth rinsing with $0.2 \%$ chlorhexidine [31]. This level of risk reduction is comparable to the systemic administration of AP [31]. Other antiseptics, such as iodine compounds and diluted oxygenated water, are also effective. According to Basilio et al., povidone-iodine and chlorhexidine are the best antiseptics [32]. Some researchers suggest that in the reduction of bacteraemia related to periodontal non-surgical treatment, an ultrasonic scaler may remove part of the bacteria by the flushing action of the water irrigation, but others disagree, suggesting higher tissue trauma. The recommended procedures are diverse - full mouth ultrasonic scaling, a combination with hand instruments and 10 minutes of scaling and root planning - hampering the comparison of results [16]. Another recommended management is avoiding the most invasive dental procedures and replacing these procedures with non-surgical dental treatment. Additionally, some research 
does not suggest dental treatment before surgical valve approaches in order to reduce the risk of IF. According to de Souza et al., the dental preparation before cardiac surgery does not change the occurrence of IF. The need for dental treatment is equally high in patients who have developed IF and those who have not, and both groups require a similar number of visits to complete the dental treatment prior to cardiac valve surgery. The results show no significant difference in the occurrence of IF between the group with dental preparation and the group without dental preparation prior to cardiac valve surgery [33].

\section{Conclusions}

There is an ongoing debate concerning the health risks, cost-effectiveness, and practicality of the routine use of prophylactic antibiotics. The lack of effectiveness data for this practice has to be weighed against risk factors, economic costs, safety and effectiveness of the routine use of antibiotics for common dental procedures. Maintenance of meticulous oral hygiene, preventing oral infections and improving oral health should be a part of the strategy against this.

\section{Disclosure}

The author reports no conflict of interest.

\section{References}

1. Al-Fouzan AF, Al-Shinaiber RM, Al-Baijan RS, Al-Balawi MM. Antibiotic prophylaxis against infective endocarditis in adult and child patients. Knowledge among dentists in Saudi Arabia. Saudi Med J 2015; 36: 554-561.

2. Thornhill MH, Gibson TB, Cutler E, Dayer MJ, Chu VH, Lockhart PB, O'Gara PT, Baddour LM. Antibiotic prophylaxis and incidence of endocarditis before and after the 2007 AHA recommendations. J Am Coll Cardiol 2018; 72: 2443-2454.

3. Thornhill MH, Jones S, Prendergast B, Baddour LM, Chambers JB, Lockhart PB, Dayer MJ. Quantifying infective endocarditis risk in patients with predisposing cardiac conditions. Eur Heart J 2018; 39: 586-595.

4. Allen U. Infective endocarditis: updated guidelines. Can J Infect Dis Med Microbiol 2010; 21: 74-77.

5. Tsolka P, Katritsis D. Infective endocarditis prophylaxis for dental procedures in 2009: what has changed? Hellenic J Cardiol 2009; 50: 493-497.

6. Dayer M, Jones S, Prendergast B, Baddour LM, Lockhart PB, Thornhill MH. An increase in the incidence of infective endocarditis in England since 2008: a secular trend interrupted time series analysis. Lancet 2015; 385: 1219-1228.

7. Ali HM, Mustafa M, Hasabalrasol S, Elshazali OH, Nasir EF, Ali RW, Berggreen $E$, Skeie MS. Presence of plaque, gingivitis and caries in Sudanese children with congenital heart defects. Clin Oral Investig 2017; 21: 1299-1307.

8. Ito HO. Infective endocarditis and dental procedures: evidence, pathogenesis, and prevention. J Med Invest 2006; 53: 189-198.

9. Mang-de la Rosa MR, Castellanos-Cosano L, Romero-Perez MJ, Cutando A. The bacteremia of dental origin and its implications in the appearance of bacterial endocarditis. Med Oral Patol Oral Cir Bucal 2014; 19: e67-e74.

10. Pourmoghaddas Z, Meskin M, Sabri M, Norousali Tehrani MH, Najafi T. Dental caries and gingival evaluation in children with congenital heart disease. Int J Prev Med 2018; 9: 52.

11. Lockhart PB, Brennan MT, Thornhill M, Michalowicz BS, Noll J, Bahrani-Mougeot FK, Sasser HC. Poor oral hygiene as a risk factor for infective endocarditis-related bacteremia. J Am Dent Assoc 2009; 140: 1238-1244.

12. Duval X, Millot S, Chirouze C, Selton-Suty C, Moby V, Tattevin P, Strady C, Euvrard E, Agrinier N, Thomas D, Hoen B, Alla F; El-dents Association pour
l'Etude et la Prévention de l'Endocardite Infectieuse (AEPEI) Study Group. Oral streptococcal endocarditis, oral hygiene habits, and recent dental procedures: a case-control study. Clin Infect Dis 2017; 64: 1678-1685.

13. Taubert KA, Wilson W. Is endocarditis prophylaxis for dental procedures necessary? Heart Asia 2017; 9: 63-67.

14. Tubiana $S$, Blotière $P O$, Hoen $B$, Lesclous $P$, Millot $S$, Rudant J, Weill A, Coste J, Alla F, Duval X. Dental procedures, antibiotic prophylaxis, and endocarditis among people with prosthetic heart valves: nationwide population based cohort and a case crossover study. BMJ 2017; 358: j3776.

15. Maharaj B, Coovadia Y, Vayej AC. An investigation of the frequency of bacteraemia following dental extraction, tooth brushing and chewing. Cardiovasc J Afr 2012; 23: 340-344.

16. Horliana AC, Chambrone L, Foz AM, Artese HP, Rabelo Mde S, Pannuti CM, Romito GA. Dissemination of periodontal pathogens in the bloodstream after periodontal procedures: a systematic review. PLoS One 2014; 9: e98271.

17. Lockhart PB, Brennan MT, Sasser HC, Fox PC, Paster BJ, Bahrani-Mougeot FK. Bacteremia associated with toothbrushing and dental extraction. Circulation 2008; 117: 3118-3125.

18. Waghmare AS, Vhanmane PB, Savitha B, Chawla RL, Bagde HS. Bacteremia following scaling and root planning: a clinico-microbiological study. J Indian Soc Periodontol 2013; 17: 725-730.

19. Umeh OD, Sanu OO, Utomi IL, Nwaokorie FO. Factors associated with odontogenic bacteraemia in orthodontic patients. J West Afr Coll Surg 2016; 6: 52-77.

20. Birlutiu V, Birlutiu RM, Costache VS. Viridans streptococcal infective endocarditis associated with fixed orthodontic appliance managed surgically by mitral valve plasty: a case report. Medicine (Baltimore) 2018; 97: e11260.

21. Birlutiu V, Birlutiu RM. Endocarditis due to Abiotrophia defectiva, a biofilmrelated infection associated with the presence of fixed braces: a case report. Medicine (Baltimore) 2017; 96: e8756.

22. Lick SD, Edozie SN, Woodside KJ, et al. Streptococcus viridans endocarditis from tongue piercing. J Emerg Med 2005; 29: 57-59.

23. Maestre Vera JR, Gómez-Lus Centelles ML. Antimicrobial prophylaxis in oral surgery and dental procedures. Med Oral Patol Oral Cir Bucal 2007; 12: E44E52.

24. Rahman T, Ahmed SS, Khan HM, Hashmi GS, Rahman SA, Ansari KM. Comparative study of detection of bacteraemia after different oral surgical procedures. Contemp Clin Dent 2015; 6: 405-408.

25. Reis LC, Rôças IN, Siqueira JF Jr, de Uzeda M, Lacerda VS, Domingues R, Miranda KR, Saraiva RM. Bacteremia after supragingival scaling and dental extraction: culture and molecular analyses. Oral Dis 2018; 24: 657-663.

26. Nemoto H, Nomura R, Ooshima T, Nakano K. Distribution of amoxicillin-resistant oral streptococci in dental plaque specimens obtained from Japanese children and adolescents at risk for infective endocarditis. J Cardiol 2013; 62: 296-300.

27. Thornhill MH, Dayer MJ, Prendergast B, Baddour LM, Jones S, Lockhart PB. Incidence and nature of adverse reactions to antibiotics used as endocarditis prophylaxis. J Antimicrob Chemother 2015; 70: 2382-2388.

28. Cahill TJ, Dayer M, Prendergast B, Thornhill M. Do patients at risk of infective endocarditis need antibiotics before dental procedures? BMJ 2017; 358: j3942.

29. Cahill TJ, Harrison JL, Jewell P, Onakpoya I, Chambers JB, Dayer M, Lockhart P, Roberts N, Shanson D, Thornhill M, Heneghan CJ, Prendergast BD. Antibiotic prophylaxis for infective endocarditis: a systematic review and meta-analysis. Heart 2017; 103: 937-944.

30. Franklin M, Wailoo A, Dayer MJ, Jones S, Prendergast B, Baddour LM, Lockhart PB, Thornhill MH. The cost-effectiveness of antibiotic prophylaxis for patients at risk of infective endocarditis. Circulation 2016; 134: 1568-1578.

31. Sendi P, Ericsson M, Olaison L. Infective endocarditis caused by group B Streptococcus: the role of aminoglycoside-combination. J Infect 2012; 64: 127-129.

32. Basilio RC, Loducca FE, Haddad PC. Medical dental prophylaxis of endocarditis. Braz J Infect Dis 2004; 8: 340-347.

33. de Souza AF, Rocha AL, Castro WH, Ferreira FM, Gelape CL, Travassos DV, da Silva TA. Dental care before cardiac valve surgery: is it important to prevent infective endocarditis? Int J Cardiol Heart Vasc 2016; 12: 57-62. 